\title{
Antimutagenic and anticancer effects of Avicennia marina leaf extract on Salmonella typhimurium TA100 bacterium and human promyelocytic leukaemia HL-60 cells
}

\author{
Leila Karami $^{\mathrm{a}}$, Ahmad Majd ${ }^{\mathrm{b}}$, Sedigeh Mehrabian $^{\mathrm{a}}$, Mohammad Nabiuni ${ }^{\mathrm{a}}$, Mandana Salehi ${ }^{\mathrm{a}}$, \\ Saeed Irian ${ }^{\mathrm{a}, *}$ \\ a Department of Cell and Molecular Biology, Faculty of Biological Sciences, Kharazmi University, Tehran, \\ Iran \\ ${ }^{b}$ Department of Biology, Tehran North Branch of Islamic Azad University, Tehran, Iran
}

*Corresponding author, e-mail: irian@tmu.ac.ir, aryanairian2003@yahoo.com

Received 12 May 2012

Accepted 24 Sep 2012

\begin{abstract}
The present study evaluated the antimutagenic and anticancer activities of $A$. marina leaf extract. The antimutagenic activity of ethanol and water extracts of $A$. marina leaf (concentration $10 \mathrm{mg} / \mathrm{plate}$ for $48 \mathrm{~h}$ ) was evaluated using the Salmonella typhimurium TA100 strain in the Ames test with $(+\mathrm{S} 9)$ and without $(-\mathrm{S} 9)$ metabolic activation, and its anticancer effect with concentrations of $200,400,450,500,600$, and $800 \mu \mathrm{g} / \mathrm{ml}$ of ethanol extract for 24,48 , and $72 \mathrm{~h}$ on human leukaemic cell line HL-60 was assessed by MTT assay. The ethanol and water extracts of $A$. marina were revealed to have antimutagenic activity in the Salmonella mutation assay. The number of mutant colonies decreased in the presence of ethanol and water extract with $(+\mathrm{S} 9)$ and without $(-\mathrm{S} 9)$ metabolic activation. The ethanol extract showed a higher antimutagenic effect than the water extract, with an inhibition rate of $71 \%$ on the mutated bacterium. The MTT cell viability test showed an induction of cytotoxicity in HL-60 cells treated with the extract with $\mathrm{IC}_{50}$ values of 600,400 , and $280 \mu \mathrm{g} / \mathrm{ml}$ after 24,48 , and $72 \mathrm{~h}$, respectively, in a concentration and time-dependent manner. Flow cytometric analysis confirmed the induction of apoptosis in the cells. Collectively, these results suggest that the Avicennia marina leaf extract contains bioactive compounds with antimutagenic and antileukaemic effects.
\end{abstract}

KEYWORDS: Ames test, MTT assay, apoptosis

\section{INTRODUCTION}

A. marina (Forssk.) Vireh (Avicenniaceae) is commonly known as gray mangrove tree ${ }^{1}$. Mangroves contain important chemical constituents with potential medicinal properties. A. marina has been used traditionally for treatment of ulcers and skin diseases ${ }^{1,2}$. The presence of chemical compounds such as steroids, triterpens, saponins, flavonoids, alkaloids, tannins and naphthoquinones have been reported in A. marina $^{3-5}$. Interest in plants with high medicinal properties in treating diseases has grown dramatically. Several studies have now confirmed the antiviral, antibacterial and antifungal effects of $A$. marina ${ }^{2,6-8}$. The anticancer activity of naphthoquinones and their analogues from this plant on mouse skin tumour and BT-20 human carcinoma cells have been reported ${ }^{5,9}$. There are different kinds of mutagens and carcinogens in the environment ${ }^{10,11}$, most of which cause cancer by producing the reactive oxygen species which cause damage to the cells through chromosomal aberrations, gene mutations and single-strand DNA breaks ${ }^{12-14}$

One of the most common cancers is the blood cancer. Leukaemia is a group of heterogeneous neoplastic disorders of white blood cells that multiply in an uncontrolled fashion, and are unable to differentiate into mature cells ${ }^{15}$. The main treatment for the afflicted individuals is chemotherapy, but different kinds of treatments such as antibiotics, blood transfusion, radiation therapy and bone marrow transplantation, are also used for treating the disease. Although such treatments have prolonged the survival rate for the leukaemia patients, their adverse effects are difficult to cope with ${ }^{16}$, making the search for to safe and efficient drugs a necessity. For many years, a great deal of attention has been paid to natural compounds for treatment and prevention of human diseases ${ }^{17}$. There are many anticancer agents derived, in one way or another, from natural sources ${ }^{18}$. Many flavonoids, phenolic compounds and terpens have so far been evaluated and shown to induce apoptosis in different leukaemia cell lines ${ }^{19,20}$. Cell death occurs through 
distinct pathways either by apoptosis, necrosis or autophagy. Programmed cell death (apoptosis) plays an important role in the regulation of tissue turnover in most normal and cancerous tissues ${ }^{21}$.

Recent investigation has focused a great deal on A. marina to isolate bioactive components with potentials in treating certain cancers such as the breast and skin cancers ${ }^{5,9}$. In the present study, the antimutagenicity effects of A. marina leaf extract on mutated bacterium $S$. typhimurium TA100 was investigated using the Ames test. The Ames test is aimed at determining whether a substance is mutagenic ${ }^{22}$. The Ames test considers that a substance with a mutagenic effect in bacteria can be a potential carcinogen. As the test does not use a live animal model, it is therefore inexpensive, easy, and quick. Since DNA is chemically the same in all organisms, any living organism can be used to test for mutagens. Thus bacteria can be used as a first step in identifying potential human carcinogens without waiting for long-lived mammals to develop cancer. This method can also be used for anti-mutagenic activity assay of extracts of natural substances against mutagenic substances ${ }^{23-25}$. A substance, proven this way to be anti-mutagenic, can also be a potential anti-cancer agent. This study also determined the anticancer effects of A. marina extract on human promyelocytic Leukaemia HL-60 cells by MTT assay. Finally, flow cytometry analysis was used to demonstrate the apoptotic nature of the HL-60 cells cell death, induced by A. marina leaf extract.

\section{MATERIALS AND METHODS}

\section{Materials}

A. marina plants were collected from the Bordekhon (Mond protected area, Southwest of Iran).

Bacterial strain S. typhimurium TA100 was kindly provided directly by Professor Ames. HL-60 cell line was obtained from Pasteur Institute of Iran (Tehran, Iran). The cell culture medium (RPMI-1640), fetal bovine serum, and penicillin-streptomycin were purchased from Gibco BRL (Life technology, Paisley, Scotland). MTT (3-[4,5-dimethylthiazol-2-yl]-2,5 -diphenyl tetrazolium bromide) was purchased from Sigma (Germany). Primary Anti Annexin V Antibody (Abcam), Secondary Anti-rabbit IgG FITC Conjugated Antibody (Abcam), materials used in the Ames test were purchased from Merck.

\section{Preparation of A. marina extracts}

A. marina leaves were isolated, air dried and chopped finely using a blender. To ensure no contamination, powders were sterilized using the tantalization tech- nique. Dried leaves $(100 \mathrm{~g})$ were extracted in $80 \%$ ethanol and water by a Soxhlet extractor. The extracts were filtered and evaporated to dryness under reduced pressure by a rotary evaporator. The resulting residues were stored at $-20^{\circ} \mathrm{C}$. For the Ames test, the extract was dissolved in $80 \%$ ethanol and sterile distilled water was added to a final $100 \mathrm{mg} / \mathrm{ml}$, sterilized by filtration. For MTT assay, the extract was dissolved in PBS (sigma), sterilized by filtration, and subsequently diluted to appropriate working concentrations with RPMI culture medium.

\section{Preparation of bacterial strain}

Prior to performing the anti-mutagenic assay, S. typhimurium TA100 mutation was confirmed. The strain was grown on a nutrient agar plate, and the genotype was checked routinely for its histidine requirement, deep rough $(r f a)$ character, UV sensitivity ( $u v r \mathrm{~B}$ mutation) and presence of the $\mathrm{R}$ factor plasmid (Maron \& Ames 1983) ${ }^{25}$. They were stored at $-80^{\circ} \mathrm{C}$. This strain is an amino acid-dependent strain, and in the absence of an external histidine source, cells cannot grow to form colonies. The presence of the $u v r \mathrm{~B}$ mutation makes the strain sensitive to UV light. The rfa mutation changes the properties of the bacterial cell wall and causes a defective lipopolysaccharide layer that coats the bacterial surface, making the bacteria more permeable to larger molecules. The rfa mutation is indicated by sensitivity to crystal violet. The presence of $\mathrm{R}$ factor plasmid in this strain shows that they are resistant to ampicillin ${ }^{23,24}$.

\section{Preparation of the activation mixture}

The S9 liver fraction was prepared according to the method of Maron and Ames ${ }^{25}$. A crude preparation of the enzymes was obtained from the homogenized rat liver, previously treated with Aroclor to enhance liver enzyme levels and activity. Prior to mutagenicity test, the $\mathrm{S} 9$ mixture was prepared by the addition of NADP and glucose-6-phosphate to S9. Contamination-free product was achieved by adding $50 \mu \mathrm{l}$ of $\mathrm{S} 9$ mixture to top agar and pouring it on the bottom agar plate. Then it was incubated for $48 \mathrm{~h}$ at $37^{\circ} \mathrm{C}$. It was made sure that the mixture was sterile. The product was used in subsequent experiments. The S9 fraction was stored at $-80^{\circ} \mathrm{C}$.

\section{Antimutagenicity test}

Ames test is based on the plate incorporation method using S. typhimurium test strains TA 98 and TA 100 , with and without exogenous metabolic activation system, the S9 fraction in S9 mixture ${ }^{23,25}$. But for the antimutagenicity test, a modified plate incorporation 
procedure was employed to determine the effect of A. marina extract on sodium azide induced mutagenicity ${ }^{26}$. In this study sodium azide $\left(\mathrm{NaN}_{3}\right)$ was used as a mutagen.

The day prior to testing, frozen stock cultures of the test strain were grown for $12-16 \mathrm{~h}$ in nutrient broth. In brief, $0.1 \mathrm{ml}$ each of the mutagen, the plant extract, the bacterial culture and $0.5 \mathrm{mM}$ L-histidine $+0.5 \mathrm{mM}$ D-biotin were added to $2 \mathrm{ml}$ of top agar and mixed gently. This mixture was then plated on minimal agar plates and incubated at $37^{\circ} \mathrm{C}$ for $48 \mathrm{~h}$ before counting the number of revertant colonies. For negative and positive control cultures, distilled water and the mutagen were added to the top agar including bacterial culture and L-histidine + D-biotin, respectively. All experiments were performed in triplicate.

The inhibition rate of mutagenicity was calculated as $1-(T / M)\left(\right.$ Ong et $\left.\mathrm{al}^{27}\right)$, where $T$ is the number of revertants on the test plate in the presence of mutagen and plant extract, and $M$ is the number of revertants in the positive control plate. No antimutagenic effect was considered to give a value smaller than $25 \%$, a moderate effect value between $25 \%$ to $40 \%$ and a strong antimutagenicity value greater than $40 \%$ were assigned. The antimutagenic effect of the extract was also carried out using S9.

The influence of metabolic activation was tested by adding $500 \mu \mathrm{l}$ of $\mathrm{S} 9$ mixture containing all the ingredients mentioned for the antimutagenicity test to the top agar before pouring them on the bottom agar. Positive and negative controls were also included. Revertants were counted following a $48 \mathrm{~h}$ incubation of these plates at $37^{\circ} \mathrm{C}$.

\section{Cell culture}

HL-60 cells were maintained in RPMI 1640 medium supplemented with $10 \%$ fetal bovine serum and the antibiotics penicillin $(100 \mathrm{IU} / \mathrm{ml})$ and streptomycin $(100 \mu \mathrm{g} / \mathrm{ml})$. Cells were grown in a humidified incubator at $37^{\circ} \mathrm{C}$ under $5 \% \mathrm{CO}_{2}$, and used for assays during their exponential growth phase. Subculturing was performed three times a week.

Fresh solution of the crude extract $(1000 \mu \mathrm{g} / \mathrm{ml})$ was prepared by dissolving the crude extract in PBS. Serial dilutions of the fresh solution were prepared in the culture medium in 24-well plates. HL-60 cells $\left(4 \times 10^{5}\right.$ cells $\left./ \mathrm{ml}\right)$ were treated with different concentrations of crude extract $(200,400,450,500$, 600 , and $800 \mu \mathrm{g} / \mathrm{ml}$ ) for 24,48 , and $72 \mathrm{~h}$, without renewal of the medium.

The number of surviving cells was then counted using the tetrazolium (MTT) assay ${ }^{28}$. This assay is based on the reduction of MTT by the mitochondrial dehydrogenases to form an insoluble, dark blue formazan product. Only viable cells with dehydrogenase activity are able to reduce significant amounts of the MTT dye to formazan ${ }^{29}$. Finally, the optical density for each well at $570 \mathrm{~nm}$ was measured using a spectrophotometer (Milton Roy - Spectronic 21D). Drug concentrations resulting in a $50 \%$ growth inhibition $\left(\mathrm{IC}_{50}\right)$ were determined from three separate experiments.

\section{Morphological changes of the cells treated with A. marina leaf extract}

The treated and untreated cells were viewed for morphological changes under an Inverted light microscope (Biomedica).

\section{Analysis of apoptosis by flow cytometry}

HL-60 cells $\left(2 \times 10^{6}\right.$ cell/well $)$ were left untreated or treated with $600 \mu \mathrm{g} / \mathrm{ml}$ of the extract for $24 \mathrm{~h}$. After the exposure time, control and the treated cells were centrifuged for $10 \mathrm{~min}$ at $402.48 \mathrm{~g}$. Having discarded the supernatant, cells were resuspended in $1 \mathrm{ml}$ PBS prior to a recentrifugation at $402.48 \mathrm{~g}$ for $10 \mathrm{~min}$. Supernatant was discarded and $50 \mu \mathrm{l}$ of diluted primary antibody $(1 \mu \mathrm{l}$ annexin $\mathrm{V}, 100 \mu \mathrm{l}$ BSA/PBS $3 \%$ ) was added to the cells before mixing gently and incubating for $5 \mathrm{~h}$ at $4{ }^{\circ} \mathrm{C}$. Cells were then washed with $1 \mathrm{ml}$ PBS and recentrifuged. Supernatant was again discarded, and $20 \mu \mathrm{l}$ of the diluted secondary antibody $(2 \mu \mathrm{l}$ secondary antibody FITC conjugated and $40 \mu \mathrm{l} \mathrm{BSA/PBS} \mathrm{3 \% )} \mathrm{was} \mathrm{added} \mathrm{to} \mathrm{the} \mathrm{tubes} \mathrm{before}$ incubating them for $45-50 \mathrm{~min}$ in the dark and at $4{ }^{\circ} \mathrm{C}$. Later these cells were washed with $1 \mathrm{ml}$ PBS and centrifuged for $10 \mathrm{~min}$ at $402.48 \mathrm{~g}$. Supernatant was discard and $300 \mu \mathrm{l}$ of $1 \%$ formaldehyde was added to the tubes, and the tubes were kept on ice before being analysed by flow cytometry ${ }^{30}$ (Beckton Dickinson).

\section{Statistical analysis}

The results were expressed as mean \pm SEM. All experiments were performed in triplicates. Statistical analyses were performed by InSTAT-3. Statistical differences among treated and untreated cells were determined by one-way ANOVA. To compare several groups, Tukey-Kramer Multiple Comparisons Test was applied. $P$-value of less than 0.05 was considered significant.

\section{RESULTS}

\section{Antimutagenicity test}

The results of antimutagenic effects of ethanol and water extracts of A. marina are presented in Table 1. These results are expressed as the number of revertants 
Table 1 Antimutagenic effects of A. marina leaf extracts with and without metabolic activation S9.

\begin{tabular}{lrrrrrr}
\hline Concentration & \multicolumn{2}{c}{$\begin{array}{c}\text { Antimutagenic } \\
\text { effect }^{\dagger}\end{array}$} & & \multicolumn{2}{c}{$\begin{array}{c}\text { Inhibition } \\
\text { rate }\end{array}$} \\
\cline { 2 - 3 } \cline { 5 - 6 } & \multicolumn{2}{c}{$-\mathrm{S} 9$} & $+\mathrm{S} 9$ & & $-\mathrm{S} 9$ & $+\mathrm{S} 9$ \\
\hline Negative control & $24 \pm 1$ & $24 \pm 1$ & & - & - \\
Positive control & $125 \pm 7$ & $125 \pm 7$ & & - & - \\
Ethanol extract & $39 \pm 3^{*}$ & $36 \pm 5^{*}$ & & 68 & 71 \\
Water extract & $76 \pm 4^{*}$ & $78 \pm 3^{*}$ & & 36 & 37 \\
\hline
\end{tabular}

${ }^{\dagger}$ Mean \pm SEM of number of revertants per plate.

Negative control: Sterile distilled water.

Positive control: $\mathrm{NaN}_{3}$.

$-\mathrm{S} 9$ : without the metabolic activation system S9.

+S9: with the metabolic activation system S9.

* Significant compared to positive control at $P<0.001$.

per plate with and without the metabolic activation system S9. These results clearly demonstrate the ethanol extract with a strong antimutagenic effect. The inhibition rates were $68 \%$ and $71 \%$ for the ethanol $-\mathrm{S} 9$ and $+\mathrm{S} 9$ samples, respectively. The water extract was also able to inhibit the mutagenic activity of sodium azide with inhibition rates of 36 and $37 \%$ in the absence and presence of S9, respectively.

Both ethanol and water extracts significantly $(P<0.001)$ inhibited the induced mutagenic effect in the absence and presence of S9 as compared to the positive control. There was no difference in the rate of inhibition between the assays performed in the presence or the absence of $\mathrm{S} 9$, while a significant $(P<0.001)$ difference could be detected between assays including ethanol and water extracts.

\section{MTT assay}

The cell growth inhibitory effect of $A$. marina leaf extract on human cancer cell line HL-60 was determined by assessing the viability of the cells using the MTT assay. HL-60 cells were treated with crude extract at concentrations of $200-800 \mu \mathrm{g} / \mathrm{ml}$ for 24,48 , and $72 \mathrm{~h}$ in triplicates. Cell growth was reduced in the presence of crude extract.

The results of $\mathrm{IC}_{50}$ values (the concentration required to inhibit cell growth by $50 \%$ relative to the untreated sample) of 600,400 , and $280 \mu \mathrm{g} / \mathrm{ml}$ at 24, 48, and $72 \mathrm{~h}$ is shown in Fig. 1. These data demonstrate the inhibitory effect of extract on HL-60 cell growth in a concentration - and time-dependent manner.

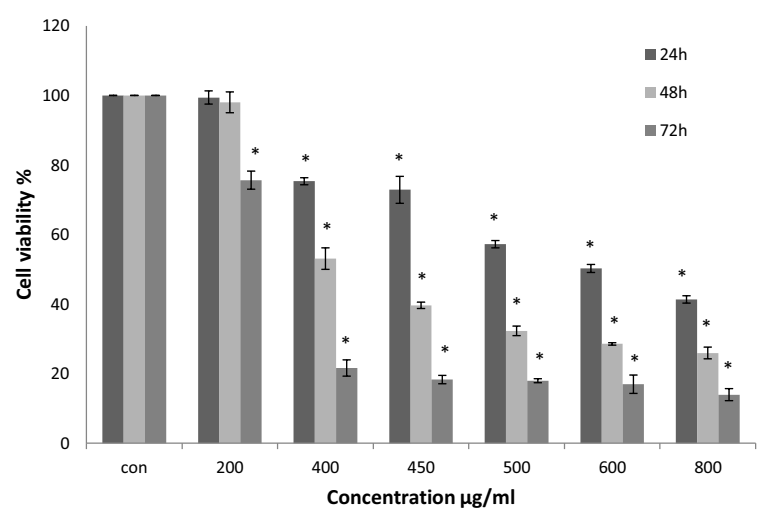

Fig. 1 Effect of $A$. marina ethanol leaf extract on the viability of HL-60 cells by MTT assay. HL-60 cells were treated with $200-800 \mu \mathrm{g} / \mathrm{ml}$ of the extract for 24,48 , and $72 \mathrm{~h}$ as described in the text. The results represent mean \pm SEM of three independent experiments. *: Significantly different from the control $(P<0.001)$.

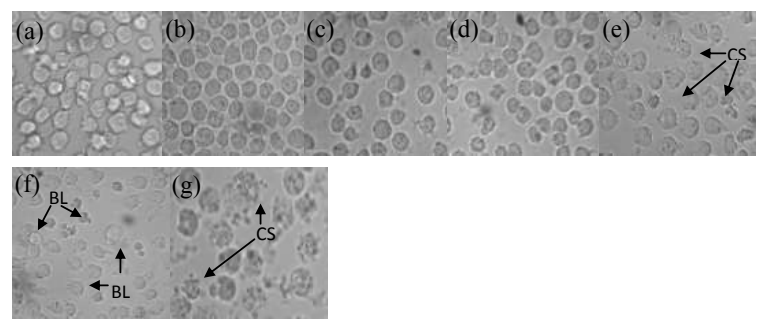

Fig. 2 Morphological changes of HL-60 cells treated with A. marina extract for $24 \mathrm{~h}$ viewed under an Inverted light microscope. Affected cells showed some features characteristic of apoptosis such as cellular shrinkage and membrane blebbing (mag. $400 \times$ ). (a) control, (b) $200 \mu \mathrm{g} / \mathrm{ml}$, (c) $400 \mu \mathrm{g} / \mathrm{ml}$, (d) $450 \mu \mathrm{g} / \mathrm{ml}$, (e) $500 \mu \mathrm{g} / \mathrm{ml}$, (f) $\mathrm{IC}_{50}$ $600 \mu \mathrm{g} / \mathrm{ml}$, (g) $800 \mu \mathrm{g} / \mathrm{ml}$.

\section{Morphological analysis}

The apoptotic effect of the extract on HL-60 cell line was also observed using light microscopy. After 24,48 , and $72 \mathrm{~h}$ of incubation with 600,400 , and $280 \mu \mathrm{g}$ of the extract, a number of cells appeared normal, whereas others exhibited dramatic morphological alterations, characteristic of apoptotic cells. Untreated HL-60 cells exhibited a round shape and a consistent size, with smooth cell membrane as shown in Fig. 2a. Extract-treated HL-60 cells, on the other hand, compared to the control cells, appeared smaller, less refracted, membrane blebbing (Fig. 2f) and with more granular material $(2 \mathrm{e}, 2 \mathrm{~g})$ in a time and concentration-dependent manner. 

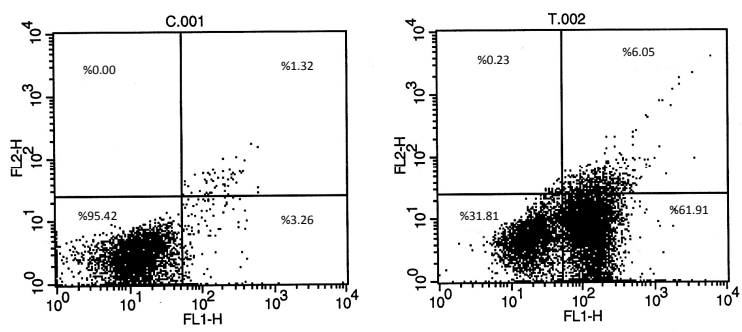

Fig. 3 Flow cytometric analysis of apoptotic cells treated with the extract for $24 \mathrm{~h}$. Control (left quadrant) and extracttreated cells (right quadrant) were subjected to primary annexin $\mathrm{V}$ antibody and secondary antibody FITC conjugated.

\section{Flow cytometric analysis}

To confirm whether the extract-induced cytotoxicity was due to apoptosis or necrosis, flow cytometric analysis of apoptosis/necrosis induced by A. marina crude extract in HL-60 cells was performed. Cells treated with $600 \mu \mathrm{g}$ extract and the control cells were incubated for $24 \mathrm{~h}$ at $37^{\circ} \mathrm{C}$ prior to being subjected to primary annexin $\mathrm{V}$ antibody and secondary antibody FITC conjugated treatments (Fig. 3). The fraction of cell population in different quadrants was analysed using quadrant statistics. Cells located in the lower left quadrant are live; cells in the lower right quadrant indicate apoptosis, while those in the upper right quadrant represent post-apoptotic population. The extract at $600 \mu \mathrm{g}$ induced $62 \%$ apoptosis. Compared to the control cells, an increase cell population affinity to annexin V-FITC was observed in extract-treated HL-60 cells.

\section{DISCUSSION}

Mangroves are good sources of natural antioxidants and are extensively used in traditional medicine. Some mangrove plants, in particular A. marina, contain abundant chemical components with antioxidant activity ${ }^{6}$. In the present study, the antimutagenic activity of A. marina leaf extracts was evaluated using the Ames test. In this respect, the ethanol extract showed a higher potential for antimutagenicity.

The moderate level of mutagenesis inhibition, observed with water extract, could be explained by the active ingredients released by the plant material into ethanol. Ethanol and water extracts + S9/-S9 exhibited nearly the same antimutagenic activity. Our results suggest a high rate of bioactivity contained within the extracts.

Zhu and colleagues reported on the presence of 123 different compounds in different parts of A. marina and its endophytes ${ }^{3}$. Compounds such as several terpenoids, steroids, naphthoquinone derivatives, flavones, glucosides have been isolated from the leaves of A. marina ${ }^{3,6}$. It is likely that these phytochemical compounds are responsible for the antimutagenic activity observed in the present study.

This study also showed a cytotoxic effect on HL-60 cell line by the ethanol extract of A. marina. HL-60 cell line has been reported to be very sensitive to apoptosis upon treatments with anti-cancer agents, and represents an ideal in vitro model for testing of antileukaemic agents ${ }^{31,32}$. Here we show that the leukaemia cells treated with different concentrations of the extract go through apoptosis as viewed under an Inverted light microscope. The latter finding was further supported by the flow cytometry analysis using primary annexin $\mathrm{V}$ antibody and secondary antibody FITC conjugated.

Our data are in line with those of Sharaf and coworkers who isolated a new flavonoid from the leaves of A. marina, and demonstrated its moderate cytotoxic effect against BT-20 human carcinoma cells with an $\mathrm{ED}_{50}$ value of $18 \mu \mathrm{g} / \mathrm{ml}^{9}$. One of the goals in using an anticancer drug/extract is the induction of apoptosis in cancer cells ${ }^{33}$. Induction of apoptosis is one of several approaches applied during cancer therapy ${ }^{34}$. Apoptosis is characterized by morphological changes of the cells including membrane blebbing, cytoplasmic and chromatin condensation, formation of apoptotic bodies, DNA fragmentation, alteration in membrane symmetry, activation of a cascade of caspases and a loss in mitochondrial membrane potential $^{35,36}$.

In the present study, the cytotoxic potential of the ethanol extract was assessed by MTT assay against the HL-60 cancer cell line. This assay is based on the reduction of yellow tetrazolium salt (MTT) by metabolically active cells to a dark blue formazan, and has been employed by many groups to measure the cytotoxic effect of any compound on cells ${ }^{29}$. A. marina leaf extract showed a significant cytotoxic effect on HL-60 cells with $\mathrm{IC}_{50}$ values of 600,400 , and $280 \mu \mathrm{g} / \mathrm{ml}$ at 24,48 , and $72 \mathrm{~h}$, respectively. To investigate the mechanism of cell death induced by the extract in HL-60 cells, flow cytometric analysis was performed using primary annexin $\mathrm{V}$ antibody and secondary antibody FITC conjugated, as a marker to assess apoptosis. During apoptosis, changes occur in cell surface markers that show affinity for annexin $\mathrm{V}^{30,37}$. In the present study, an increase in apoptotic population was induced by the extract, assigning an apoptosis inducing effect for $A$. marina leaf extract.

The antimutagenic property of $A$. marina extract against mutated $S$. typhimurium revealed by the Ames 
test is a positive step forward in determining the safe use of this plant used in traditional medicine. Toxicological studies on rats have rejected the presence of any adverse effects exhibited by A. marina leaf extract, and proved its safe use as a herbal remedy and as animal feed in drought-stricken areas ${ }^{38}$.

Phytochemical studies on A. marina leaf extract have revealed the presence of secondary metabolites such as alkaloids, flavonoids, triterpenoids and steroids, which could also be expected to be responsible for its bioactivity. These compounds with antioxidant activity can inhibit mutation and cancer because they scavenge free radicals or induce antioxidant enzymes ${ }^{6}$.

Naphthoquinones isolated from A. marina have been shown to exhibit marked inhibitory effect on mouse skin tumour promotion ${ }^{5}$. Naphthoquinones are one group of secondary metabolites widespread in nature. Naphthoquinone-induced cell death has been determined in many cancer cell lines. The cytotoxic effect of these compounds is based on the generation of reactive oxygen species and induction of apoptosis ${ }^{39}$.

Plants with naphthoquinone content are used in traditional medicine, and might serve as leads for the development of novel drugs with a putative anticarcinogenic activity ${ }^{40}$.

In conclusion, the results of the present study firstly indicate that A. marina leaf crude extract inhibits mutation in mutated S. typhimurium TA100 and induces apoptosis in HL-60 cell line. These findings suggest that the extract may contain a bioactive compound that kills human promyelocytic leukaemia cells, HL-60 cells, by an apoptosis mechanism, as confirmed by flow cytometry analysis, and that it can serve as a candidate for the development of anti-cancer herbal agents against HL-60 cells.

Acknowledgements: The authors are thankful to the Faculty of Biological Sciences at Kharazmi University for the support for this work. The authors are also thankful to the staff at Bushehr Environmental Office and Mond Protected Area for their help in plant sample collection.

\section{REFERENCES}

1. Kathiresan k Bingham BL (2001) Biology of mangroves and mangrove ecosystems. Adv Mar Biol 40, 81-251.

2. Bandaranayake WM (1998) Traditional and medicinal uses of mangroves. Mangroves Salt Marshes 2, 133-48.

3. Zhu F, Chen X, Yuan Y, Huang M, Sun H, Xiang W (2009) The chemical investigations of the mangrove plant Avicennia marina and its endophytes. Open Nat Prod J 2, 24-32.
4. Khafagi I, Gab-Alla A, Salama W, Fouda M (2003) Biological activities and phytochemical constituents of the gray mangrove Avicennia marina (Forssk.) Vierh. Egypt J Biol 5, 62-9.

5. Itoigawa $\mathrm{M}$, Ito $\mathrm{C}$, Tan HT, Okuda M, Tokuda $\mathrm{H}$, Nishino H, Furukawa H (2001) Cancer chemopreventive activity of naphthoquinones and their analogs from Avicennia plants. Canc Lett 174, 135-9.

6. Abeysinghe PD, Wanigatunge RP, Pathirana RN (2006) Evaluation of antibacterial activity of different mangrove plant extracts. Ruhuna J Sci 1, 104-12.

7. Ravikumar S, Gnanadesigan M, Suganthi P, Ramalakshmi A (2010) Antibacterial potential of chosen mangrove plants against isolated urinary tract infectious bacterial pathogens. Int J Med Med Sci 2, 94-9.

8. Zandi K, Taherzadeh M, Yaghoubi R, Tajbakhsh S, RastianZ, Fouladvand M, Sartavi K (2009) Antiviral activity of Avicennia marina against herpes simplex virus type 1 and vaccine strain of poliovirus (an in vitro study). J Med Plant Res 3, 771-5.

9. Sharaf M, El-Ansari MA, Saleh NAM (2000) New flavonoids from Avicennia marina. Fitoterapia 71, 274-7.

10. Møller P, Wallin H, Knudsen LE (1996) Oxidative stress associated with exercise, psychological stress and life-style factors. Chem Biol Interact 102, 17-36.

11. Namiki M (1990) Antioxidants/antimutagens in food. Crit Rev Food Sci Nutr 29, 273-300.

12. Clarkson PM, Thompson HS (2000) Antioxidants: What role do they play in physical activity and health? Am J Clin Nutr 72, , 637S-46S.

13. Chen SC, Chung KT (2000) Mutagenicity and antimutagenicity studies of tannic acid and related compounds. Food Chem Toxicol 38, 1-5.

14. Rueff J, Brás A, Cristóvão L, Mexia J, Sáda Costa M, Pires V (1993) DNA strand breaks and chromosomal aberrations induced by $\mathrm{H}_{2} \mathrm{O}_{2}$ and ${ }^{60} \mathrm{Co} \gamma$-radiation. Mutat Res 289, 197-204.

15. Lee SJ, Kim KH, Park JS, Jung JW, Kim YH, Kim SK, Kim WS, Goh HG, et al (2007) Comparative analysis of cell surface proteins in chronic and acute leukemia cell lines. Biochem Biophys Res Comm 357, 620-6.

16. Chiang LC, Cheng HY, Liu MC, Chiang W, Lin CC (2004) In vitro evaluation of antileukemic activity of 17 commonly used fruits and vegetables in Taiwan. $L W T$ Food Sci Tech 37, 539-44.

17. Chin YW, Balunas MJ, Chai HB, Kinghorn AD (2006) Drug discovery from natural sources. AAPS $J \mathbf{8}$, 239-53.

18. Cragg GM, Newman DJ (2003) Plants as a source of anti-cancer and anti-HIV agents. Ann Appl Biol 143, 127-33.

19. Huang WW, Yang JS, Lin CF, Ho WJ, Le MR (2005) Pycnogenol induces differentiation and apoptosis in human promyeloid leukemia HL-60 cells. Leuk Res 29 , 685-92.

20. Stanoeva E, He W, Kimpe ND (2005) Natural and 
synthetic cage compounds incorporating the 2, 9, 10trioxatricyclo 4.3.1.03, 8 decane type moiety. Bioorg Med Chem 13, 17-28.

21. Majno G, Joris I (1995) Apoptosis, oncosis, and necrosis: an overview of celldeath. Am J Pathol 146, 3-15.

22. McCann J, Ames BN (1976) Detection of carcinogens as mutagens in the Salmonella/microsome test: Assay of 300 chemicals: Discussion. Proc Natl Acad Sci Unit States Am 73, 950-4.

23. Ames BN, McCann J, Yamasaki E (1975) Methods for detecting carcinogens and mutagens with the salmonella/mammalian microsome mutagenicity test. Mutat Res 31, 347-63.

24. Ames BN, Durston WE, Yamasaki E, Lee FD (1973) Carcinogens are mutagens: A simple test system combining liver homogenantes for activation and bacteria for detection. Proc Natl Acad Sci Unit States Am $\mathbf{7 0 ,}$ 2281-5.

25. Maron DM, Ames BN (1983) Revised method for the Salmonella mutagenicity test. Mutat Res 113, 173-215.

26. Lee K, Sohn I (2000) Essential moiety for antimutagenic and cytotoxic activity of hederagenin monodesmosides and bisdesmosides isolated from the stem bark of Kalopanax pictus. Planta Med 66, 329-32.

27. Ong T, Whong WZ, Stewart JD, Brockman HE (1986) Chlorophyllin: a potent antimutagen against environmental and dietary complex mixtures. Mutat Res Lett 173, 111-5.

28. Allen RT, Hunter WJ III, Agrawal DK (1997) Morphological and biochemical characterization and analysis of apoptosis. J Pharmacol Toxicol Meth 37, 215-28.

29. Mosmann T (1983) Rapid colorimetric assay for cellular growth and survival: Application to proliferation and cytotoxicity assays. J Immunol Meth 65, 55-63.

30. Van Engeland MV, Nieland LJW, Ramaekers FCS, Schutte B, Reutelingsperger CPM (1998) Annexin VAffinity assay: A review on an apoptosis detection system based on phosphatidylserine exposure. Cytometry 31, 1-9.

31. Suh N, Luyengi L, Fong HH, Kinghorn AD, Pezzuto JM (1995) Discovery of natural product chemopreventive agents utilizing HL-60 cell differentiation as a model. Anticancer Res 15, 233-40.

32. Yoshida A, Ueda T, Nakamura T (1996) The mechanism of apoptosis induced by anticancer agents in human leukemia HL60 cells. Rinsho Ketsueki 37, 552-7.

33. Denicourt C, Dowdy CS (2004) Medicine targeting apoptotic pathways in cancer cells. Science $\mathbf{3 0 5}$, 1411-3.

34. Los M, Burek CJ, Strol C, Bnedyk K, Hug H, Mackiewicz A (2003) Anticancer drugs of tomorrow: Apoptotic pathways as targets for drug design. Drug Discov Today 8, 67-77.

35. Kaufman SH, Earnshaw WC (2000) Induction of apoptosis by cancer chemotherapy. Exp Cell Res 256, 42-9.

36. Studzinski GP (1999) An overview of apoptosis. In: Studzinski GP (ed) Apoptosis: A Practical Approach.
Oxford Univ Press, Oxford.

37. Vermes I, Haanen C, Steffens-Nakken H, Reutelingssperger C (1995) A novel assay for apoptosis. Flow cytometric detection of phosphotidylserine expression on early apoptotic cells using fluorescein labelled Annexin V. J Immunol Meth 184, 39-51.

38. Ali BH, Bashir AK (1998) Toxicological studies on the leaves of Avicennia marina (mangrove) in rats. J Appl Toxicol 18, 111-6.

39. Babula P, Adam V, Havel L, Kizek R (2009) Noteworthy secondary metabolites naphthoquinones - their occurrence, pharmacological properties and analysis. Curr Pharmaceut Anal 5, 47-68.

40. Lee SE, Hyun JH, Ha JS, Jeong HS, Kim JH (2003) Screening of medicinal plant extracts for antioxidant activity. Life Sci 73, 167-79. 